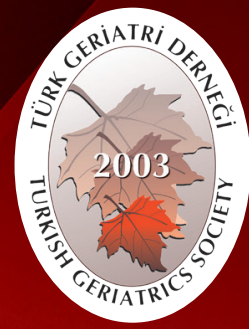

Turkish Journal of Geriatrics DOI: 10.31086/tigeri.2018.53 2018;21 (4):490-497

- Burcu ARPINAR YiĞiTBAŞ ${ }^{1}$

- Celal SATICI

- Elif TANRIVERDi 1

- Canan GÜNDÜZ²

CORRESPONDANCE

Burcu ARPINAR YIĞiTBAŞ

Yedikule Chest Disease and Chest Surgery

Research and Training Hospital, Chest Diseases Clinic, Istanbul, Turkey

Phone: 2124090200

e-mail: drburcuayigitbas@yahoo.com

Received: 15/01/2018

Accepted: 22/10/2018

Yedikule Chest Disease and Chest Surgery Research and Training Hospital, Chest

Diseases Clinic, İstanbul, Turkey

Ege University, Faculty of Medicine,

Department of Chest Diseases, İzmir, Turkey
RESEARCH

\section{INFLUENZA VACCINATION FREQUENCY AND ASSOCIATED FACTORS AMONG ELDERLY POPULATION, A DESCRIPTIVE STUDY}

\section{Abstract}

Introduction: Influenza vaccination is the most effective method of preventing influenza infection in elderly, reducing complications, hospitalizations and mortality rates due to influenza. This study aimed to assess the frequency of influenza vaccination, attitude about the vaccine, and reasons why not getting vaccinated in individuals aged $>65$ years.

Materials and Method: In total, 598 participants aged $>65$ years were enrolled in this descriptive study, and data were collected via a face-to-face survey.

Results: In total, $22 \%$ of the 598 participants received the influenza vaccine. The top three reasons for not seeking vaccination were not knowing about the influenza vaccine $(45.2 \%)$, feeling of no need to get vaccinated $(21.2 \%)$, and not believing in the influenza vaccine's effectiveness (10.9\%). Participants who had chronic obstructive pulmonary disorder, heart failure, and ischemic heart disease were vaccinated more than participants who had other comorbidities. Among participants, advice from their physician was noted as an effective means for prompting vaccination (OR, 20.34; 95\% Cl, 10.17-40.70).

Conclusion: We evaluated the reasons associated with the low influenza vaccination frequency among the elderly. Informing the elderly of the benefits of receiving the influenza vaccine should be encouraged. Communication between healthcare providers and people aged $>65$ years is essential for improving vaccination frequency.

Keywords: Aged; Comorbidity; Hospitalization; Influenza vaccines; Surveys and questionnaires; Vaccine refusal

\section{ARASTIRMA}

\section{YAŞLILARDA GRIP AŞISI SIKLIĞI VE ILIŞKILI FAKTÖRLER, TANIMLAYICI BIR ÇALIŞMA}

\section{$\ddot{O}_{z}$}

Giriş: Yaşlı bireylerde influenza aşısı, influenza hastalığının önlenmesinde en etkili yöntem olup influenzanın komplikasyonlarını, hastane yatışlarını ve ölüm oranlarını azaltmaktadır. Bu çalışmada 65 yaş üzeri bireylerde, influenza aşısı yaptırma sıklığı, bireylerin aşı hakkındaki tutumları ve aşılanmama nedenleri değerlendirilmiştir.

Gereç ve Yöntem: Bu tanımlayıcı çalışmaya 65 ve yaş üzeri toplamda 598 kişi katılmıştır ve veriler yüz yüze anket yoluyla toplanmıştır.

Bulgular: Toplamda 598 katılımcıdan \%22'si influenza aşısı olmuştur. Aşı yaptırmamak için ilk üç neden, grip aşısı hakkında bilgi sahibi olmama (\%45.2), aşılanmaya ihtiyaç duymama (\%21.2) ve grip aşısının etkinliğine inanmama (\%10.9) idi. Kronik obstrüktif akciğer hastalığı, kalp yetmezliği ve iskemik kalp hastalığı olan katılımcılar, diğer komorbiditelere sahip olanlardan daha fazla aşılanmış idi. Katılımcılar arasında doktorlarından aldıkları tavsiye, aşılamanın yapılmasında etkili bir araç olarak görülmüştür (OR, 20.34; \%95 GA, 10.17-40.70).

Sonuç: Bu bulgular ile yaşlılarda düşük influenza aşılama oranları ile ilişkili nedenler değerlendirilmiştir. İnfluenza aşısının yapılmasının yararları hakkında bilgilendirilmeler teşvik edilmelidir. Sağlık hizmeti sağlayıcıları ile 65 yaş üstü kişiler arasındaki iletişim, aşı oranlarının iyileştirilmesi için şarttır.

Anahtar sözcükler: Anket; Aşı reddi; Grip aşısl; Hastane yatışları; Komorbidite; Yaşlı 


\section{INTRODUCTION}

Influenza is a seasonal viral infection that typically occurs during the winter months and is capable of spreading easily. The influenza viruses can cause pandemics and severe illnesses, leading to hospitalizations, and even death in children and the elderly. A report from the Centers for Disease Control and Prevention in 2015 indicated that $3 \%-5 \%$ of residents of the USA were affected by influenza. Hospitalizations were reported in over 200,000 patients because of influenza-associated complications. These annual epidemics are estimated to result in about 3-5 million cases of severe illness worldwide, and approximately $250,000-500,000$ deaths, with most deaths in industrialized countries occurring among people aged $\geq 65$ years (1). Influenza infections usually cause milder symptoms lasting for 5-7 days in healthy adults, whereas it can cause severe pulmonary symptoms such as primary influenza, pneumonia, and secondary bacterial infections that contribute to morbidity and mortality, especially among individuals aged $\geq 65$ years (2).

A simple and effective way to prevent influenza infections is annual vaccination. The United States Advisory Committee on Immunization Practices recommends universal annual influenza vaccinations for all individuals aged $\geq 6$ months (3). The influenza vaccination not only reduces the risk of influenza infection but also reduces the severity of the illness in those who are infected $(4,5)$. The Turkish Ministry of Health recommends and supplies free influenza vaccines to a wide range of individuals, including pregnant women; individuals aged $\geq 65$ years; children aged 6 months to 2 years; residents of nursing homes and other chronic-care facilities; individuals who suffer from chronic pulmonary (including asthma), cardiovascular, renal, hepatic, neurologic, hematologic, or metabolic disorders [including diabetes mellitus (DM)]; individuals with obesity; health care personnel; and individuals aged 6 months to 18 years and receiving long-term aspirin therapy. Annual immunization is necessary even if the previous year's vaccine contains one or more of the antigens to be administered because the immunity declines during the year following vaccination $(4,6)$.

This investigation assesses the influenza vaccination frequency and the associated factors that influence the vaccination of those aged $\geq 65$ years attending outpatient clinics in Yedikule Research and Training Hospital for Chest Diseases and Chest Surgery.

\section{MATERIALS AND METHOD}

\section{Participants}

This descriptive study was conducted between October 2015 and June 2016 in a tertiary hospital, Yedikule Research and Training Hospital for Chest Diseases and Chest Surgery, Istanbul, Turkey. Participants were randomly selected from patients who were aged $\geq 65$ years and who had an appointment at the hospital's outpatient clinic. Initially, selected patients were given a minimental test (7). The most commonly used test for dementia scanning is the mini mental test. It is evaluated over 30 points and it is determined that the ideal threshold value is 24 in the Turkish society for mild dementia.

The participants of the test were asked whether they had any allergic reactions to the influenza vaccine and were excluded from the investigation if they had experienced any allergic reaction.

\section{Sample size}

The prevalence of influenza vaccination was assumed to be $20 \%$, and the sample size was calculated with a significance level of 0.05 and a power level of 0.80. Dementia patients and nonresponders were assumed to represent $5 \%$ of the population. A minimum sample size of 660 participants was required. 


\section{Data collection}

Data was collected via a face-to-face survey that was developed through a comprehensive literature search and was finalized after the pilot study with 15 participants. Sociodemographic features, comorbidities, vaccination status, knowledge about the influenza vaccine, and reasons for not being vaccinated were assessed in the questionnaire.

The research was approved by Yedikule Research and Training Hospital for Chest Diseases and Chest Surgery Ethics Committee (2015/04). Oral informed consent was obtained from every participant before starting the questionnaire.

\section{Statistical analysis}

Continuous variables are expressed as mean \pm standard deviation (SD). Statistics were calculated using the Student's t-test. Descriptive statistics were created for questions with responses expressing frequencies and percentages. The chi-square and Fisher's exact tests were used as appropriate. Univariate and multivariable logistic regression analyses were conducted to evaluate associations between vaccination and demographic features and patients' knowledge. Odds ratios (OR) and $95 \%$ confidence intervals $(\mathrm{Cl})$ were calculated. A p-value $<0.05$ was considered statistically significant.

\section{RESULTS}

Thirty-two out of 660 participants with a minimental score <24 (4.6\%) and 9 (4.5\%) nonresponders were excluded from the study. In total, 598 participants completed the questionnaire. All participants were aged 65-93 years (median, 71 years; interquartile range, 9 years). The majority of participants were males (M: $F=1.56)$. Among participants, $74.75 \%$ were graduated from at least elementary school, $11.2 \%$ were active smokers, $46.5 \%$ had quit smoking, and $42.3 \%$ never smoked. Chronic obstructive pulmonary disorder (COPD) was found in $39.0 \%$, asthma in $14.9 \%$, diabetes mellitus (DM) in 13\%, heart failure (HF) in $23.9 \%$, hypertension (HT) in 9.5\%, ischemic heart disease (IHD) in 3.5\%, and miscellaneous comorbidities in $11.6 \%$ of the population. $11.2 \%$ of the participants were healthy. Table 1 shows the characteristics of participants according to vaccination status. In total, 131 out of 598 participants received the influenza vaccine $(22.0 \%$; $95 \% \mathrm{Cl}, 21.87-21.93)$. The three most common reasons for not getting vaccinated (Figure 1) were as follows: (1) didn't know much about influenza vaccine (45.2\%), (2) didn't need to get vaccinated (21.2\%), and (3) didn't believe the influenza vaccine was effective (10.9\%). Other reasons included forgetting about the vaccination period, prior adverse reactions (other than allergic reactions), pain, being ill at the time, costs, and other miscellaneous reasons.

Among vaccinated participants, there was a greater percentage of educated (graduated from at least elementary school) individuals compared to uneducated (illiterate) individuals ( $15.9 \%$ vs $23.9 \%, p=0.039$ ). Among comorbidities, participants with COPD (28.3\%, $p=0.02), \mathrm{HF}$ (15.4\%, $p=0.031)$, and $\operatorname{IHD}(33.3 \%, p=0.001)$ had significantly higher vaccination frequency.

The majority of the respondents (67.4\%) were aware of the influenza vaccine. However, vaccination frequency was only $32.5 \%$ among these individuals. Knowledge and perception of the influenza vaccine of the participants are shown in Table 2. Participants who had heard of the vaccine from doctors were more vaccinated than other participants $(\mathrm{OR}, 20.34 ; 95 \% \mathrm{Cl}, 10.17$ 40.70; $p=0.001$ ). Recommended by any healthcare worker was the most influential factor to get vaccinated with an OR, $73.26(95 \% \mathrm{Cl}, 34.46-$ 155.76; $p=0.001)$. Participants were more likely to get vaccinated when they were recommended by a chest physician $(\mathrm{OR}, 4.82 ; 95 \% \mathrm{Cl}, 2.02-11.46$; $p=0.016$ ). Knowing that the influenza vaccine is free of charge for individuals aged 65 years was a promoter of vaccine $(\mathrm{OR}, 36.35$; $95 \% \mathrm{Cl}, 16.257-$ 79.74; $p=0.001$ ). 
Table 1. Characteristics of participants according to vaccination status.

\begin{tabular}{|c|c|c|c|c|}
\hline & Not vaccinated $\mathrm{n}(\%)$ & Vaccinated n (\%) & $p$ & OR $(95 \% \mathrm{Cl})$ \\
\hline & $467(78.0)$ & $131(22.0)$ & & \\
\hline Age (median, IQR) & $71(9)$ & $70(9)$ & 0.515 & \\
\hline $\begin{array}{l}\text { Gender } \\
\text { Male } \\
\text { Female }\end{array}$ & $\begin{array}{l}267(77.0) \\
200(79.7) \\
\end{array}$ & $\begin{array}{l}80(23.0) \\
51(20.3) \\
\end{array}$ & 0.485 & \\
\hline $\begin{array}{l}\text { Education } \\
\text { Non-Educated } \\
\text { Educated }\end{array}$ & $\begin{array}{l}127(84.1) \\
340(76.1)\end{array}$ & $\begin{array}{r}24(15.9) \\
107(23.9)\end{array}$ & 0.039 & $\begin{array}{r}\text { Ref } \\
1.66(1.02-2.71)\end{array}$ \\
\hline $\begin{array}{l}\text { Smoking habit } \\
\text { Nonsmoker } \\
\text { Smoker } \\
\text { Exsmoker }\end{array}$ & $\begin{array}{r}206(81.4) \\
54(80.6) \\
207(74.5) \\
\end{array}$ & $\begin{array}{l}47(18.6) \\
13(19.4) \\
71(25.5) \\
\end{array}$ & $\begin{array}{r}0.092 \\
0.599 \\
\mathbf{0 . 0 4 5} \\
\end{array}$ & $\begin{array}{r}\text { Ref } \\
1.05(0.53-2.09) \\
1.50(0.99-2.28) \\
\end{array}$ \\
\hline $\begin{array}{l}\text { Comorbidities } \\
\text { COPD doesn't exist } \\
\text { COPD exists }\end{array}$ & $\begin{array}{l}300(82.2) \\
167(71.7)\end{array}$ & $\begin{array}{l}65(17.8) \\
66(28.3)\end{array}$ & 0.02 & $\begin{array}{r}\text { Ref } \\
2.03(1.25-3.26)\end{array}$ \\
\hline $\begin{array}{l}\text { Asthma doesn't exist } \\
\text { Asthma exists }\end{array}$ & $\begin{array}{r}399(78.4) \\
68(76.4)\end{array}$ & $\begin{array}{r}110(21.6) \\
21(23.6)\end{array}$ & 0.676 & $\begin{array}{r}\text { Ref } \\
1.61(0.86-3.00)\end{array}$ \\
\hline $\begin{array}{l}\text { DM doesn't exist } \\
\text { DM exists }\end{array}$ & $\begin{array}{r}408(78.5) \\
59(75.6)\end{array}$ & $\begin{array}{r}112(21.5) \\
19(24.4)\end{array}$ & 0.574 & $\begin{array}{r}\text { Ref } \\
1.50(0.81-2.78)\end{array}$ \\
\hline $\begin{array}{l}\text { HF doesn't exist } \\
\text { HF exists }\end{array}$ & $\begin{array}{l}346(76.0) \\
121(84.6)\end{array}$ & $\begin{array}{r}109(24.0) \\
22(15.4)\end{array}$ & 0.031 & $0.73(0.41-1.28)$ \\
\hline $\begin{array}{l}\text { HT doesn't exist } \\
\text { HT exists }\end{array}$ & $\begin{array}{r}422(78.0) \\
45(78.9)\end{array}$ & $\begin{array}{r}119(22.0) \\
12(21.1)\end{array}$ & 0.870 & $\begin{array}{r}\text { Ref } \\
0.78(0.36-1.65)\end{array}$ \\
\hline $\begin{array}{l}\text { IHD doesn't exist } \\
\text { IHD exists }\end{array}$ & $\begin{array}{r}453(78.5) \\
14(66.7)\end{array}$ & $\begin{array}{r}124(21.5) \\
7(33.3)\end{array}$ & 0.001 & $\begin{array}{r}\text { Ref } \\
2.28(0.82-6.31)\end{array}$ \\
\hline
\end{tabular}

Bold characters indicate statistical significance $\mathrm{p}<0.05$; IQR: interquartile range, COPD: Chronic obstructive pulmonary, DM: Diabetes mellitus, HF: Heart Failure, HT: Hypertension, IHD: İschemic Heart Disease.

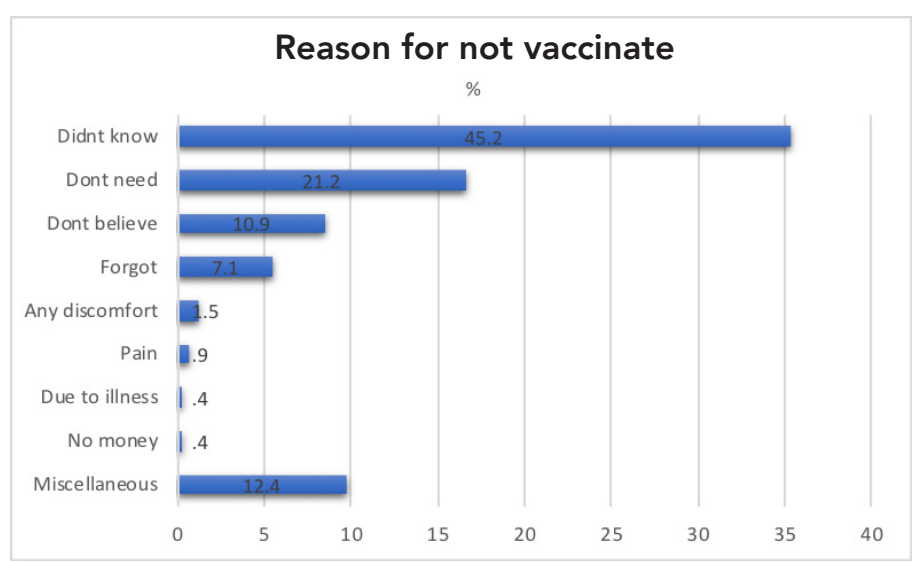

Miscellaneous: Concerns about getting flu, laziness, residence in another city at the vaccine interval

Figure 1. Reasons for receiving the influenza vaccine. 
Table 2. Participants' knowledge and perception of influenza vaccine.

\begin{tabular}{|c|c|c|c|c|}
\hline & Not vaccinated $\mathrm{n}(\%)$ & Vaccinated n (\%) & $\begin{array}{r}\text { Univariate } \\
\text { analysis } \\
\mathbf{p}\end{array}$ & $\begin{array}{r}\text { Multivariate analysis OR, } \\
95 \% \mathrm{Cl}\end{array}$ \\
\hline \multicolumn{5}{|c|}{$\begin{array}{l}\text { Heard of influenza } \\
\text { vaccine before? }\end{array}$} \\
\hline No & 195 (100) & $0(0)$ & 0.001 & \\
\hline Yes & $272(67.5)$ & $131(32.5)$ & & \\
\hline \multicolumn{5}{|c|}{ If yes from whom? } \\
\hline Media & $109(88.6)$ & $14(11.4)$ & $<0.001$ & Ref \\
\hline Pharmacist & $49(68.1)$ & 23 (31.9) & 0.001 & $3.65(1.73-7.70)$ \\
\hline Doctors & $31(27.7)$ & $81(72.3)$ & $<0.001$ & $20.34(10.17-40.70)$ \\
\hline Miscellaneoust & $83(86.5)$ & $13(13.5)$ & 0.630 & $1.21(0.54-2.73)$ \\
\hline \multicolumn{5}{|l|}{$\begin{array}{l}\text { Ever been } \\
\text { recommended }\end{array}$} \\
\hline No & $386(98.0)$ & $8(2.0)$ & & Ref \\
\hline Yes & $81(39.7)$ & $123(60.3)$ & $<0.001$ & $73.26(34.46-155.76)$ \\
\hline \multicolumn{5}{|c|}{ If yes from whom? } \\
\hline Pharmacist & $24(65.0)$ & $13(35.0)$ & 0.005 & Ref \\
\hline Family doctor & $31(37.3)$ & $52(62.7)$ & 0.006 & $3.10(1.38-6.94)$ \\
\hline Chest Phys. & $18(27.7)$ & $47(72.3)$ & 0.001 & $4.82(2.02-11.46)$ \\
\hline Miscellaneousł & $8(42.0)$ & $11(58.0)$ & 0.107 & $2.53(0.81-7.88)$ \\
\hline \multicolumn{5}{|c|}{$\begin{array}{l}\text { Did you know the } \\
\text { vaccine is free }>65\end{array}$} \\
\hline No & $264(97.4)$ & $7(2.6)$ & & Ref \\
\hline Yes & $153(55.2)$ & $124(44.8)$ & 0.001 & 36.35 (16.57-79.74) \\
\hline
\end{tabular}

\section{DISCUSSION}

This investigation was the first to present the frequency of vaccination, knowledge, and behaviors of the influenza vaccination of Turkish residents aged $\geq 65$ years. The findings suggest that the frequency of influenza vaccination, knowledge, and recommendation is quite low among participants. Former studies in Turkey showed similar results. In particular, Ciblak et al. in 2012 searched two national medical databases and PubMed using terms associated with relevant diseases and vaccination frequency and reported a vaccination coverage frequency for individuals aged $\geq 65$ at $5.9 \%$ and for patients with COPD at $14.9 \%$ (8). Another recent study from Turkey by Akturk et al. included COPD patients from six different centers, which included a total of 296 patients and concluded that the frequency of influenza vaccination is $36.5 \%$ (9). Ciftci et al reported $33.4 \%$ vaccination frequency among patients admitted to outpatient clinic with a mean age of 47.7 years (10). Present study showed that the vaccination frequency is $22.0 \%(95 \% \mathrm{Cl}$, $21.87-21.93)$ for people who aged $\geq 65$ years and $28.3 \%$ vaccination frequency $(95 \% \mathrm{Cl}, 0.226-0.346)$ 
in COPD patients. However, the results reported herein are still lower than those reported in European countries and other countries of the world. Sevin et al. conducted a survey-based study in an urban environment using a multicultural population in Central Ohio, USA, reported a $51.5 \%$ immunization frequency (11). Likewise, a different study from Kansas, USA, Santaularia et al, showed a $64.8 \%$ vaccination frequency within people aged $\geq 65$ years (12). According to an Australian study conducted by Dyda et al., $57.3 \%$ of individuals aged $\geq 65$ years were vaccinated in the previous year (13), whereas Bödeker et al. reported 49\% in those older than 60 years in Germany (14). According to GP reports, Mangtani demonstrated that $85 \%$ of men and $75 \%$ of women aged $\geq 74$ years were vaccinated against influenza in London (15).

Present study showed no differences in vaccination prevalence between age and gender. However, in our study educated participants were more often vaccinated than noneducated ones (OR, 1.665; 95\% Cl, 1.023-2.711; $\mathrm{p}=0.039$ ). Responders who had quit smoking tended to get the flu vaccine more than active smokers and nonsmokers (OR, 1.50; 95\% Cl, 0.992-2.279; $\mathrm{p}=0.045$ ). Akturk et al reported that gender, marital status, and smoking habits had no effect on the pneumococcal or influenza vaccination frequency (9). In Ciftci's study Among the vaccinated patients, the ratio of patients with an educational level of high-school or above (60.6\%) was greater than that of patients with a lower educational level (39.4\%) (10).

In the present study participants who had COPD, HF, and IHD (1) were vaccinated more often than participants who had other comorbidities (OR, 2.03; OR, 0.73; OR, 2.28; respectively). Bödeker et al. mentioned if an underlying chronic disease exists and not specified, stated that $56.3 \%$ of participants aged 60 years and older who had an underlying chronic disease got vaccinated (OR, 2.07) (14). In addition, Ciftci et al showed that vaccination frequency were greater among those with chronic lung disease (43.6\%), heart disease (21.2\%), and diabetes mellitus (19.3\%) (10).

Results from the present study highlight popular reasons why individuals do not get vaccinated. The majority of the patients (45.2\%) did not have information about the influenza vaccine. The second main reason was the belief that they did not need the vaccine (21.2\%). Participants made comments such as "I don't get flu, so I don't need the vaccine." $10.9 \%$ of participants mentioned that they did not believe the vaccine was effective, so they did not get vaccinated. Yeung et al. showed that the majority of the cases (80.8\%) were not aware that they were recommended the influenza vaccine and among the controls (71\%), a high percentage of participants deemed vaccination to be unnecessary. Similar to our study, the authors mentioned that this finding showed a failure in communicating the importance of the vaccination to this age group (16). Sevin et al. reported ethnic disparities in the knowledge of the influenza vaccine indication, including concern for getting sick from the following treatment (11). Another study by Santalauria et al. reported a $64.8 \%$ vaccination frequency and stated that adults aged $\geq 65$ years had Medicare coverage and might likely have other medical conditions that could steer them toward receiving the vaccination (12). In Ciblak's study, the most common reported reason for not becoming vaccinated was that the "vaccine is not effective," which was reported in $46 \%$ of participants. The second most reported reason was that the "vaccine causes influenza," which was reported by $26 \%$ of participants (8). Ciftci et al reported the reasons of not getting vaccinated were considering the vaccine useless $(\mathrm{OR}, 2.46)$, having concerns about side-effects 
$(O R, 2.14)$ and having inadequate knowledge $(O R, 7.12)(10)$. Akturk et al. had similar results, the most notable reason for not being vaccinated for influenza or pneumococcus was 'my doctor didn't advise me to' $(57.2 \%$ for influenza and $46.8 \%$ for pneumococcus vaccine) (9). Dyda et al. mentioned that in all unvaccinated participants, the most frequent reason for not obtaining the vaccine was a perception of being at low-risk of contracting influenza (26.7\%), not having thought about the influenza vaccination (21.5\%) and a mistrust of the vaccination (18.3\%). Among those opposed to the vaccine, older people rejected vaccination more frequently than younger individuals ( $<60$ years, 7.8\%;>60 years, 15.9\%) (13).

In present study $67.5 \%$ of nonvaccinated and $32.5 \%$ of vaccinated participants had heard of the influenza vaccine before. In contrast to the vaccinated group, individuals have heard of the vaccine mostly from doctors, pharmacies, and media. Getting information about the flu vaccine from doctors could improve the likelihood of the individual becoming vaccinated (OR, 20.34, $p<0.001$ ) (Table 2). Among participants recommended to receive the vaccine, $60 \%$ are ultimately vaccinated $(O R, 73.26, p=0.001)$. Ciftci's study showed men, as compared to women, had a significantly greater frequency of considering the vaccine useful $(p<0.001)$, getting vaccinated during campaigns held by workplaces $(p=0.002)$, and obtaining information through bills, brochures, or bulletins $(p=0.003)(10)$.

This study suggests that recommendation by chest physicians was associated with vaccination $(O R, 4.82, p=0.016)$. This finding is similar to those being recommended by the family doctor and was associated with vaccination. Knowing that the vaccine is free of charge in those aged $\geq 65$ years impacts the vaccination frequency (OR, 36.35, $p=0.001$ ). Ciftci et al reported similar results among participants who had been informed by doctors had more vaccination frequency (10).

One of the limitations of present study is that it cannot be generalized due to a single centered study; therefore, results should be interpreted in this way. Secondly, the study was conducted using a nonvalidated survey and the participants' knowledge, awareness of influenza disease, and associated complications were not questioned.

In conclusion, despite the intense efforts of the Ministry of Health, including free vaccination, extensive recommendations to those aged $>65$ years, and improved accessibility throughout the country, the current vaccination frequency was determined low. This study's objective was to investigate vaccination frequency and related factors among those aged $\geq 65$ years. These findings suggest that participants rely on family doctors and specialists that they are familiar with to make a recommendation, which they will value. However, if general practitioners emphasize the value of the influenza vaccine to the patient's life and insist on vaccination, a higher frequency of influenza vaccination could be seen. This study's findings are practical and will likely lead to increased awareness among the society in both patients and doctors. The communication between doctors and individuals must be improved with regard to developing novel and efficient influenza vaccination policies. Participant responses to the questionnaire may suggest that responders use media so that it can be empowered more efficiently.

\section{ACKNOWLEDGMENTS}

Our special thanks to the MECOR family; A. Sonia Buist, MD; Pinar Ay, MD, MPH; Tricia LeVan, PhD, $\mathrm{CPH}$; Metin Akgun, MD; and Ozge Yilmaz, MD. 


\section{REFERENCES}

1. Aktürk ÜA, Dilektaşlı $A G$, Şengül $A$, et al. Influenza and pneumonia vaccination rates and factors affecting vaccination among patients with chronic obstructive pulmonary disease. Balkan Med J 2017;34(3):206-211. (PMID:28443565).

2. Bödeker B, Remschmidt C, Schmich P, Wichmann $\bigcirc$. Why are older adults and individuals with underlying chronic diseases in Germany not vaccinated against flu? A population-based study. BMC Public Health 2015;15:618-27. (PMID:26148480).

3. Castilla J, Godoy P, Domínguez A, et al; CIBERESP Cases and Controls in Influenza Working Group Spainet al. Influenza vaccine effectiveness in preventing outpatient, inpatient, and severe cases of laboratory-confirmed influenza. Clin Infect Dis 2013;57(2):167-75. (PMID:23532475).

4. Ciblak MA, Flu Platform. Influenza vaccination in Turkey: Prevalence of risk groups, current vaccination status, factors influencing vaccine uptake and steps taken to increase vaccination rate. Vaccine 2013;31(3):518-23. (PMID:23174194).

5. Ciftci F, Sen E, Demir N, Kayacan O. Which factors effects patients belief and attitudes about influenza vaccination? Tuberk Toraks 2017;65(4):308-316. (PMID:29631530).

6. Dyda A, Karki S, Hayen A, et al. Influenza and pneumococcal vaccination in Australian adults: a systematic review of coverage and factors associated with uptake. BMC Infect Dis 2016;16(1):515-29. (PMID:27670446).

7. Ehrlich HJ, Singer J, Berezuk G, et al. A cell culturederived influenza vaccine provides consistent protection against infection and reduces the duration and severity of disease in infected individuals. Clin Infect Dis 2012;54(7):946-54. (PMID:22267715).

8. Grohskopf LA, Sokolow LZ, Broder KR, et al. Prevention and control of seasonal influenza with vaccines. MMWR Recomm Rep 2016;65(5):1-54. (PMID:27560619).
9. Güngen C, Ertan T, Eker E, Yaşar R, Engin F. Standardized Mini Mental Test validity and reliability as a diagnostic tool of dementia in Turkish population. Turkish Physciatry 2002;13(4):273-81. (PMID:12794644).

10. Kamboj M, Sepkowitz KA. Risk of transmission associated with live attenuated vaccines given to healthy persons caring for or residing with an immunocompromised patient. Infect Control Hosp Epidemiol 2007;28(6):702-07. (PMID:17520544).

11. Mangtani P, Breeze E, Stirling S, Hanciles S, Kovats A, Fletcher A. Cross-sectional survey of older peoples' views related to influenza vaccine uptake. BMC Public Health 2006;6:249-55. (PMID:17034625).

12. Santaularia J, Hou W, Perveen G, Welsh E, Faseru B. Prevalence of influenza vaccination and its association with health conditions and risk factors among Kansas adults in 2013: a cross-sectional study. BMC Public Health 2016;16:185-90. (PMID:26911615).

13. Sevin AM, Romeo C, Gagne B, Brown NV, Rodis JL. Factors influencing adults' immunization practices: a pilot survey study of a diverse, urban community in central Ohio. BMC Public Health 2016;16:424-31. (PMID:27216805).

14. Thompson WW, Weintraub E, Dhankhar P, et al. Estimates of US influenza-associated deaths made using four different methods. Influenza Other Respir Viruses 2009;3(1):37-49. (PMID:19453440).

15. Treanor JJ. Influenza vaccination. N Engl J Med 2016;375(13):1261-8. (PMID:27682035).

16. Yeung MP, Ng SK, Tong ET, Chan SS, Coker R. Factors associated with uptake of influenza vaccine in people aged 50 to 64 years in Hong Kong: a casecontrol study. BMC Public Health 2015;15:617-23. (PMID:26148496). 